\title{
Escritos do Visconde de Ouro Preto e outros Autores sobre o Golpe Republicano
}

\author{
Escritos del Vizconde de Ouro Preto y otros Autores \\ sobre el Golpe Republicano
}

\author{
Writings of the Viscount of Ouro Preto and other Authors \\ on the Republican Coup
}

Dr. Ronaldo Raemy Rangel ${ }^{1}$

\author{
Ma. Gabriel Dolabela Raemy Rangel ${ }^{2}$
}

\begin{abstract}
Resumo
Afonso Celso de Assis Figueiredo, Visconde de Ouro Preto, foi o ultimo Presidente do Gabinete Ministerial (ou Primeiro-ministro) do Império do Brasil. Após a Proclamação da República, no exílio, escreveu um folhetim intitulado Advento da ditadura militar no Brasil, no qual oferece sua versão sobre o que chamou de "sublevação militar que derrubou a monarquia brasileira". Baseado no texto de Ouro Preto e em outros autores que relatam os eventos que deram origem a República, o artigo pretende sustentar que a verdadeira causa que esteia o do movimento republicano não é a republica em si, mas a descentralização do poder e o estabelecimento de um pacto federativo no país. O texto defende também, que os eventos que geraram o estabelecimento da república, em certo sentido, se deram de forma precipitada, sem comando e, principalmente, sem envolvimento popular, caracterizando-se como um golpe, sendo que o relato do Visconde de Ouro Preto, a despeito de contraargumentos que lhe possam ser apresentados, é o fio condutor da argumentação que o artigo apresenta.
\end{abstract}

Palavras-Chave: República; Federalismo; Golpe; Visconde de Ouro Preto.

\section{Resumen}

Afonso Celso de Assis Figueiredo, vizconde de Ouro Preto, fue el último presidente del gabinete ministerial (o primer ministro) del Imperio de Brasil. Después de la Proclamación de la República, en el exilio, escribió un folleto titulado Adviento de la dictadura militar en Brasil, en el cial ofrece su versión de lo que llamó "la agitación militar que derrocó a la monarquía brasileña". Basado en el texto de Ouro Preto y otros autores que informan sobre los acontecimientos que dieron origen a la República, el artículo pretende mantener que la verdadera causa que subyace al movimiento republicano no es la república en sí, sino la descentralización del poder y el establecimiento de un pacto federativo en el país. El texto también argumenta que los eventos que generaron el establecimiento de la república, en cierto sentido, tuvieron lugar de manera apresurada, sin comando y sin participación popular, caracterizándose como un golpe de estado y la cuenta del Vizconde de Ouro Preto, a pesar de los contraargumentos que se le pueden presentar, es el hilo conductor del argumento presentado por el artículo.

Palabras clave: República; Federalismo; Golpe: Vizconde de Ouro Preto.

Abstract

${ }^{1}$ Doutor em Desenvolvimento Econômico pela Unicamp; Professor de MBA e coordenador na FGV; São Paulo, São Paulo, Brasil; rrrangel@fgvmail.br

${ }^{2}$ Mestre em Direito pela UGF: Doutorando em Sociologia e Direito na UFF; Professor da UCAM; Rio de Janeiro, Rio de Janeiro, Brasil; gabrieldolabelaadv@globo.com 
Afonso Celso de Assis Figueiredo, Viscount of Ouro Preto, was the last President of the Ministerial Cabinet (or Prime Minister) of the Empire of Brazil. After the Proclamation of the Republic, in exile, he wrote a booklet entitled Advent of the military dictatorship in Brazil, in which he offers his version of what he called "the military upheaval that overthrew the Brazilian monarchy". Based on the text of Ouro Preto and other authors who report the events that gave rise to the Republic, the article intends to maintain that the real cause that underlies the republican movement is not the republic itself, but the decentralization of power and the establishment of a federative pact in the country. The text also argues that the events that generated the establishment of the republic, in a certain sense, took place in a hasty manner, without command and, mainly, without popular involvement, being characterized as a coup. The booklet of the Viscount of Ouro Preto, despite any counter-arguments that may be presented to him, is the guiding thread of the argument presented by the article.

Keywords: Republic; Federalism; Coup; Viscount of Ouro Preto.

\section{Introdução: O prenúncio do golpe republicano}

D. Pedro II permaneceu por quase sessenta anos à frente da monarquia, mantendo a unidade e integridade do território em uma região cercada por repúblicas. Tal fato só foi possível graças a certa representação simbólica utilizada pela monarquia brasileira, principalmente por aqueles que apresentavam o monarca como um homem esclarecido, que exercia seu poder e seu papel a partir de justiça, ordem, paz e equilíbrio (SCHWARCZ, 1999). Assim, há quem diga que D. Pedro II era maior que a monarquia a qual representava.

Mas, com certeza, a principal fonte de estabilidade e equilíbrio da monarquia brasileira no período do Segundo Reinado foi o café, que possibilitava o crescimento da renda, não só para a região cafeeira, como para o país como um todo. Acerca da geração de riqueza derivada da cafeicultura, Celso Furtado, após constatar que o produto per capita ficou praticamente estagnado na primeira metade do século XIX, estimou um crescimento da renda per capita da região de lavouras de café de $2,3 \%$ na segunda metade do século, e uma taxa de 1,5\% ao ano para o restante do país, (FURTADO, 2003, p. 153-155). Segundo Furtado, tal fenômeno - guardadas as devidas e necessárias restrições para o caso de um país essencialmente agrícola - se deu acompanhado pela relativa expansão do setor manufatureiro, de atividades financeiras e comerciais.

Em reforço ao argumento, valemo-nos de Caio Prado Jr., que, citado por Fernando Novais, nos alerta:

No Brasil inaugura-se um novo plano que desconhecera no passado, e nascia para ávida moderna de atividades financeiras. Um incipiente capitalismo dava aqui seus primeiros e modestos passos. A incorporação das primeiras companhias e sociedades, com seu ritmo acelerado e apesar dos exageros e de certo artificialismo, assimila assim mesmo o início de um processo de concentração de capitais que embora ainda acanhado representa ponto de partida para uma nova fase inteiramente nova. (PRADO JR. Apud NOVAIS., 1979, p.193). 
Como se percebe, os anos de prosperidade econômica foram marcados por novas relações sociais de produção que, gradativamente, se distanciavam das relações típicas que davam forma à agricultura mercantil-escravista. E a mentalidade da elite rural demorou para se ajustar às modernas exigências decorrentes das novas relações sociais de produção que se estabeleceram ao longo do Império, mas principalmente no período do Segundo Reinado. Visto de hoje, tal processo poderia ser explicado pelo fenômeno da "circulação das elites" (RODRIGUES, 1984), porém não no sentido renovação de quadros, mas no de adaptação dos quadros.

Seja como for, a chegada da segunda metade do século XIX traz consigo o esvaziamento da hegemonia da elite, não só a da corte, mas também a fluminense, notadamente pelo advento e fortalecimento da classe dirigente de outras regiões do país, principalmente a paulista, assim como, por exemplo, nos apresenta Edgard Carone:

A partir de 1870, a classe dirigente paulista começa a se sobressair no jogo do poder, tendo uma representatividade singular no Império e na República. Ainda divididos em facções ideológicas e políticas, os paulistanos se apresentam com republicanos e monarquistas, positivistas e agnósticos, evolucionistas e católicos, mas, pragmaticamente, são uníssonos na questão da sua hegemonia sobre a sociedade. (CARONE, 2001, p. 13).

Inegavelmente, na segunda metade do século XIX o arranjo social era pressionado e precisava ser revisto e, em um primeiro momento, representantes da elite tradicional buscaram fazê-lo, sem, contudo, alterar o equilíbrio de um Estado burocrático patrimonialista, o que consideravam necessário para impedir a emergência ou a efetiva circulação do poder político. São nestes restritos termos que um dos aspectos determinantes para o sucesso da gestão do Segundo Reinado é estabelecido: o Gabinete da Consolidação (1853-58).

O gabinete, cujo ministério tinha metade das cadeiras ocupadas por liberais e metade por conservadores, gerou estabilidade tamanha que o conservador Honório Ernesto Carneiro Leão, o Marquês do Paraná, foi seu presidente por três anos consecutivos e, inclusive, o indivíduo a exercer o cargo por mais tempo. A estabilidade política que o Brasil viveu na segunda metade do século XIX certamente influenciou a visão dos grupos dominantes quanto à manutenção de um Estado soberano que introduzia no país elementos da modernidade e que, acima de tudo, estabelecia o derradeiro distanciamento da herança colonial e do desejo de que nos transformássemos em um "imenso Portugal". 3

\footnotetext{
${ }^{3}$ Fernando Novais (1977) define o chamado antigo sistema colonial, afirmando que as relações entre Portugal e suas colônias não eram dicotômicas e sim dialéticas. Assim, o Brasil não seria uma mera colônia, mas parte de
} 
Note-se que Gilberto Freyre (1990), ao analisar a formação da sociedade brasileira em Sobrados e mucambos, afirma ser importante destacar, não apenas os impactos da formação do Estado, mas também o contexto das transformações e mudanças políticas, econômicas e ideológicas, além da introdução de máquinas e a formação de um (mesmo que incipiente) mercado capitalista. Freyre conclui que a cultura urbana que se instaura passa a considerar a oposição entre valores burgueses europeus e valores locais vindos do interior.

Em sentido análogo, Florestan Fernandes nos ensina que:

(...) pela organização de um Estado nacional, gradualmente uma parcela em aumento crescente de "senhores rurais" é extraída do isolamento do engenho ou da fazenda e projetada no cenário econômico das cidades e no ambiente político da Corte ou dos Governos Provinciais. Por aí se deu o solapamento progressivo do tradicionalismo vinculado à dominação patrimonialista e começou a verdadeira desagregação econômica, social e política do sistema colonial. (FERNANDES, 1975, p. 27).

$\mathrm{O}$ afastamento do sistema colonial, em verdade, caracteriza um processo em que dois fatores são marcantes e, em certo sentido, dão forma à economia da época: o aumento da importância relativa do trabalho assalariado e a gestação do mercado interno. Entretanto, no caso brasileiro - país que se mantinha dependente do trabalho escravo - a modernidade assume uma formação ambígua e complexa, que pode, novamente, ser compreendida em Florestan Fernandes:

Simplificando as coisas, seria possível reduzir a três constelações psicossociais que governavam, no período escravocrata, os ajustamentos dos libertos ao trabalho livre: a noção de que a liberdade significa plena disposição da pessoa sobre si mesma, cujo corolário prático dava a cada indivíduo o arbítrio de decidir o quanto, onde e como trabalhar; a representação segundo a qual a dignidade do homem livre é incompatível com serviços degradantes; e o princípio pré-capitalista de que a dedicação ao trabalho deve ser regulada pelas necessidades de consumo do indivíduo com seus dependentes. (FERNANDES, 1965, p. 48).

Em complemento, o mesmo Fernandes, em A revolução burguesa no Brasil (1975), afirma que, com a abolição da escravatura, desencadeou-se no último quartel do século XIX uma "ordem social competitiva" em um contexto em que, no país, o capitalismo não possuía as bases materiais para se desenvolver. De toda forma, o prof. Florestan considera aquele momento como a única revolução social acontecida no Brasil, visto que, em sua visão, a

um projeto maior que visava construir um "imenso Portugal". Reforçando o argumento, o livro de Evandro de Melo (2002), traz diversas interpretações sobre o regime colonial português, sobre o qual vale lembrar que poucas monarquias europeias estiveram presente em tantas e tão diversas regiões do globo, sendo que o chamado império colonial português se inicia no século XIII e só termina em 1999, com a entrega de Macau ao governo chinês. 
passagem da estrutura escravista para o trabalho livre correspondeu a mudanças na ordenação e na dinâmica da população do país.

Por seu turno, Nelson Werneck Sodré, em Introdução à revolução brasileira (1978), atesta que, na abolição e após ela, os contrastes apenas foram fixados, pois as classes dominantes ainda detinham a concentração da propriedade rural, urbana e familiar. De toda forma, a tentativa brasileira de encontrar a modernidade, não se deu de maneira linear e, muito mesmo, pacífica. Retomando Sobrados e mucambos, Freyre (1990) percebeu que neste processo houve a construção de instituições importantes para uma ordem moderna, como o Estado e o mercado (considerando-se, novamente, as dimensões possíveis de um mercado no Brasil do século XIX). Segundo ele, as instituições Estado e mercado permitiram o estabelecimento de bases universais que traçam a tipologia do Brasil moderno, sem, contudo, reduzir o constante embate entre os dois já mencionados sistemas distintos, ou dois modelos antagônicos de valores.

Parece ser diante desta contradição que a Constituição de 1824 estabeleceu como o Poder Moderador deveria ser exercido. O Poder Moderador - o quarto Poder - assumia para os defensores da monarquia a expressão máxima do centralismo decisório estatal, uma marca do Estado imperial brasileiro e um dos principais elementos para a estabilidade do Império. É como nos ensina Oliveira Viana:

Uma constituição política de caráter acentuadamente descentralizado e com um poder central débil e ineficiente, por mais liberal e democrática que fosse, seria ali uma construção perfeitamente fora da realidade, formosamente edificada com a mais pura argila doutrinária, mas absolutamente incapaz de garantir à sociedade a sua segurança externa e, portanto, de garantir, na sua vida interna, a realização do direito. (VIANA, 1922, p.10, 11).

De fato, durante as décadas do chamado segundo Reinado, o temor da perda da unidade nacional justificava a existência do quarto Poder, mas vale lembrar que a experiência de um poder constitucional com capacidade de ingerência sobre os demais poderes e outros aspectos da vida do Império de modo algum tinha aceitação unânime. Resumidamente, havia aqueles que afirmavam que o Poder Moderador representava a harmonia entre os demais. Indo além, existia uma linha de interpretação que dizia que qualquer forma de controle sobre o Poder Moderador significava uma inversão de soberania e a própria revogação da monarquia. Por fim, havia aqueles, menos republicados e mais federalistas, para quem o Poder Moderador deveria ser extinto. O debate se acirra quando o apogeu econômico do período começa a declinar com o abalo provocado pelas quebras no comércio e na indústria, o 
que, não sem motivo, coincide com o início do fim da lógica de conciliação entre liberais e conservadores.

Cabe observar que há várias interpretações sobre a origem da crise econômica da época. Contudo, para os fins aqui propostos, devemos lembrar como certo que, em 1864, o café havia caído 15 pontos nas Bolsas de Mercadoria de Londres e Nova Iorque, e o açúcar, mais de 30. O câmbio, contudo, manteve-se estável e o governo tinha definido os limites do socorro tecnicamente possível de ser prestado pelo Banco do Brasil, sendo que algumas casas bancárias já o haviam ultrapassado. Uma delas, a Antônio José Alves Souto \& Cia., das mais importantes do país, não pôde mais honrar os saques e fechou suas portas no dia 10 de setembro de 1864 .

A "quebra do Souto" foi o prenúncio de outras crises que viriam. Por exemplo, em maio de 1875, o Banco Mauá-MacGregor entra em moratória, na sequência o Banco Nacional suspende os pagamentos, e finalmente, o Banco Alemão também se vê obrigado a fechar as portas. Visto que os bancos da época estavam ligados ao monopólio comercial (como a Casa Souto) ou ao esboço de indústria manufatureira existente no país (como o Mauá-MacGregor, de Irineu Evangelista de Souza, o Barão de Mauá), pode-se supor que a crise e a insolvência se propagaram, impactando os tradicionais produtores, incluindo os agrícolas.

É o início do fim do Império.

\section{As condições econômicas para o golpe republicano}

Há farta literatura apresentando e analisando as questões que antecederam a proclamação da República. Mas nos parece que não foram, necessariamente, as questões militar e religiosa, a influência do positivismo ou a insatisfação pela não indenização aos proprietários de escravos após a abolição que determinaram o fim do Império. Provavelmente, as carolices da Princesa Isabel e a arrogância do príncipe consorte, o qual se temia pudesse ser o governante de fato, tiveram tanta importância para a fragilização da monarquia quanto as demais questões. Na verdade, pode-se imaginar o tamanho da má vontade do povo brasileiro com o Conde d'Eu por uma carta enviada por D. Pedro II à Princesa Isabel, na qual o imperador faz uma "analogia” entre o genro e príncipe Alberto, consorte da Rainha Vitória do Reino Unido. Lê-se na carta que infelizmente foi perdida no incêndio do Museu Nacional do Brasil em 2018: 
Para que qualquer Ministério não tenha o menor ciúme da ingerência de minha filha nos negócios públicos é indispensável que meu genro, alias conselheiro natural de minha filha, proceda de modo que não se possa ter certeza de que ele influiu, mesmo por seus conselhos, nas opiniões de minha filha. (...) mais robusteci minha convicção pelas qualidades que lhe reconheci depois, de que ele seguiria o exemplo do esposo da rainha Vitória, o príncipe Alberto. (CARTAS DE D. PEDRO, s/d)

Curiosidades de lado, com certeza a maior vulnerabilidade da monarquia - e a causa de seu fim - residia na crise econômica que se agravara por conta das dívidas decorrentes da Guerra do Paraguai. Para se ter ideia da magnitude da crise, a dívida extrema do Império em 1870 acumulava doze milhões de libras esterlinas, sendo que após a guerra totalizava quase $£$ 30 milhões. (ABREU e LAGO, 2001).

Com efeito, informações sobre a atividade econômica no Brasil do século XIX são extremamente precárias e sua imprecisão permite apenas seu uso como referência de grandeza. De toda maneira, estimativas do IBGE concernentes ao período 1840-1889, permitem avaliar a produção agropecuária da época. Não há, entretanto, dados confiáveis sobre os demais setores da economia, embora os professores da PUC-Rio Marcelo Abreu e Luiz do Lago estimem, em seu já citado texto para discussão, que os setores secundário e terciário provavelmente correspondiam a 50\% do PIB em 1889.

E é exatamente nesses setores que a crise se instala de maneira contundente em meados da década de 1870. Note-se que desde a década anterior as contas públicas estavam acumulando déficits e, ao fim da Guerra do Paraguai, ficaram em frangalhos. Agravando a conjuntura, uma seca sem precedentes assolava o Nordeste do país e o tipo de grão do café produzido e exportado (principalmente no Rio de Janeiro) passa a perder espaço e a ser substituído por outras variedades do produto no mercado internacional. Assim, a economia escravista começa a dar claros sinais de saturação. Para debelar a inflação crescente o governo retirou $20 \%$ do meio circulante do país, além de - pressionado por alas conservadoras da elite agrária - ter fixado por lei obstáculos para a organização da iniciativa privada em setores não agrícolas, a qual ficou conhecida como Lei dos Entraves.

Com efeito, parte da burocracia estatal acreditava que a causa dos problemas econômicos residia na forma pouco rigorosa como o crédito era concedido e como os contratos creditícios, com baixas garantias, eram estabelecidos, possibilitando que os bancos privados atuassem de forma especulativa e mesmo temerária. Com esse espírito, medidas contumazes foram adotadas, dificultando e fragilizando a posição das casas bancárias nacionais, atraindo para o país vários bancos estrangeiros (principalmente ingleses), motivados não apenas pelas transações bancárias propriamente ditas, mas também pelo intuito 
de financiar obras, principalmente de infraestrutura, realizadas com garantias estatais.

O crescimento da concorrência bancária não trousse tranquilidade ao setor financeiro da época e, pelo contrário, criou uma competição desigual, já que os bancos estrangeiros tinham a vantagem do lastro em moeda conversível diante da adoção rigorosa do padrão ouro, ${ }^{4}$ que, como nos ensina Donald Moggridge, era necessário para estabilizar o câmbio em um pais exportador de produtos primários:

A extraordinária característica da era anterior a 1914 foi a manutenção de um regime de taxas fixas de câmbio entre os países mais industrializados por quase 35 anos sem a escora de restrições cambiais, controle de importações e particularidades semelhantes, em que poucos países abandonaram o padrão após tê-lo adotado e desvalorizações e re-valorizações cambiais foram exceções. (MOGGRIDGE, 1987, p. 2).

Esse momento de crise se agrava pela dificuldade da elite cafeicultora tradicional, que se financiava pela lógica de geração de valor no escravismo. Há um vídeo que circula na Internet, no qual Ricardo Amorim (AMORIM, s/d) afirma que, no Brasil, sempre que há uma crise econômica, no momento seguinte estabelece-se uma ruptura política. Assim, se aceitarmos que há um padrão histórico entre crise econômica e crise política (e vice-versa), podemos considerar que todas as outras questões históricas apontadas como causas do fim do Império não possuem efetivamente o peso que normalmente lhe atribuem.

A economia, ou mais especificamente, a necessidade de mudança radical do modelo econômico aqui adotado é que se transforma na força que impelirá para a mudança do regime político. A proposta republicana de ordem e progresso ganhava espaço, pois foi percebida como uma possibilidade de transição econômica ou como uma solução para a situação de crise do país. Com efeito, é a crise econômica que cria e alimenta a crise política que desaguou na República. Entretanto, os problemas da economia não cessam com o advento do novo regime e marcarão os primeiros governos republicanos e os primórdios do século XX.

\section{A política e o discurso republicano}

É inegável que, nos meses que antecederam o golpe republicano, a população, de modo geral, e grande parte da classe dominante tinham cada vez menor apreço ao Império e duvidavam da sua capacidade de reagir ao confuso quadro político que se estabelecia e a uma crise econômica que se consolidava. O tomo sete da obra História geral da civilização

\footnotetext{
${ }^{4}$ É um sistema monetário que dominou a política econômica dos principais países europeus do final do século XIX até a primeira metade da década de 1920.
} 
brasileira, é o livro Do Império à República (1992), no qual Sergio Buarque de Holanda relata que, ao ser indicado para presidir o gabinete, em 1889, o Visconde de Ouro Preto apresenta à Câmara seu programa de governo propondo amplas reformas para aplacar insatisfações tanto de conservadores, quanto de liberais, mas principalmente de republicanos.

Ocorre que Ouro Preto havia sido a terceira ou quarta tentativa de Pedro II para formar o gabinete. O Senador Manoel Francisco Correia (o Sen. Correia) não havia aceitado a indicação, assim como também não aceitaram outros políticos. Buarque de Holanda explica inclusive que o senador maranhense Luiz Antônio Vieira da Silva chegou a tentar formar o gabinete, "conciliando duas alas inconciliáveis do partido conservador (...), Não conciliou nada e não fez o ministério" (BUARQUE DE HOLANDA, 1992, p. 355).

Seja como for, Ouro Preto, de fato, apresentou propostas audaciosas naquele mês de julho de 1889. Existe um texto superinteressante, do próprio Ouro Preto, originalmente publicado em Paris, no ano de 1891, e recentemente reeditado pelo Senado Federal, intitulado "Advento da ditadura militar no Brasil" (2017), no qual o Visconde relata a sessão da Câmara:

\begin{abstract}
Se programa havia que naturalmente pudesse influir para a transformação dos partidos e principalmente dos partidos constitucionais, esse programa era o do gabinete a que presidi. Se transformação não houve, culpa não foi seguramente do governo. Com efeito, qual o procedimento dos conservadores, sem embargo dos aplausos fervorosos ao presidente do conselho, na exposição de sua doutrina?

A esses aplausos seguiu-se uma moção de desconfiança que a maioria em peso votou, fazendo sentir ao ministério que entre ele e essa maioria nenhuma aproximação era possível: um repto de morte. (In. Senado Federal, 2017, p 134).
\end{abstract}

Acontece que, embora as medidas apresentadas pelo chefe do gabinete em 7 de junho de 1891 propusessem consolidar na legislação o maior poder e iniciativa para os súditos e mais autonomia administrativa para os municípios e províncias, tais proposituras estavam condicionadas ao não enfraquecimento do Estado, ou seja, ao poder central. Assim, nenhuma de suas propostas tratavam de uma das questões postuladas, e talvez a mais relevante, pelos opositores: a federação.

Em seu livro, Sergio Buarque de Holanda (1992) explica que o exemplo federativo dos Estados Unidos e mesmo da vizinha Argentina $^{5}$ influenciavam de forma marcante a ideia federativa que ganhava corpo no país. Há uma frase, aparentemente proferida por Cesário

\footnotetext{
${ }^{5}$ Em 1853, foi sancionada a primeira Constituição argentina, a qual consagra os princípios da Federação Argentina e a distribuição de competência entre o governo federal e as províncias.
} 
Alvim, bastante elucidativa daquele momento: "se não vem a federação, que venha a República".

Pretendia-se então com o golpe obter mais federalismos e menos república? Vale aqui explorar algumas ideias sobre o tema, sendo que para a primeira delas é necessário lembrar que o conceito de federalismo ${ }^{6}$ e, principalmente, de Estado federal eram à época relativamente recentes, mas já apontam dois princípios básicos para constituir um governo descentralizado. O primeiro princípio é o da participação dos chamados estados membros, princípio que equivale à vontade política da organização federativa. $\mathrm{O}$ segundo é o princípio da autonomia, por meio do qual os estados membros têm liberdade para estabelecer suas próprias Constituições, instituindo para si todos os mesmos poderes de que goza o governo central. Nesses termos, a Constituição Federal cumpre o papel de definir as condições básicas e comuns do pacto federativo.

Merece destaque o fato de que o Manifesto do Partido Republicano, de 1870, que criticou o governo central e a monarquia, utilizando até mesmo expressões como "realeza aventureira", "despotismo real" etc., se baseava na federação como seu mais forte argumento e justificativa. Sob a alegação da extensão territorial e diversidade do Brasil, o manifesto indicou o modelo federativo como uma meta republicana e como a melhor alternativa para lidar com realidade nacional.

Contudo, autores como Paulo Bonavides afirmam que:

Antes de 1891 os focos de supostas resistências federalistas contra o Império não devem ser confundidos com movimentos provinciais de exploração autonomista, que em verdade não existiam: eram antes erupções políticas de coronéis e caudilhos, dominados por uma consciência mais de âmbito feudal e diâmetro comunitário de que propriamente provincial. (BONAVIDES, 2004, p.15).

De toda maneira, inequivocamente a federação foi usada como bandeira pelos republicanos, que, em seu manifesto, fazem menção a uma certa "revolução da democracia em 1831”, que levou à abdicação de D. Pedro I e pouco depois ao Ato Adicional de 1834, marco da descentralização no período imperial. Com efeito, a Lei da Interpretação do Ato Adicional de 1834 era reiteradamente levantada e criticada como uma ação tipicamente discricionária do "único poder constituinte que tem existido no Brasil" que, se valendo de um

\footnotetext{
${ }^{6}$ Somente a partir de obra de Pierre-Joseph Proudhon, O princípio federativo (2001), é que foi possível compreender como uma concepção teórica o governo federal descentralizado. Destaque-se que o livro, publicado originalmente em 1863, teve a primeira tradução em português em 1874.
} 
poder centralizado, "sequestrou a liberdade política das províncias".7 Portanto, o viés republicano, inspirado na Constituição dos Estados Unidos da América, prometia a descentralização política e uma nova e mais saudável relação entre o governo central e as províncias do país. São nesses termos que o primeiro decreto do Governo Provisório Republicano (chamado literalmente de Decreto Federal do Brasil, $n^{\circ}$ 1) estabelece no seu artigo $2^{\circ}$ que "as Províncias do Brasil, reunidas pelo laço da federação, ficam constituindo os Estados Unidos do Brasil”.

\section{O golpe pelo olhar de Ouro Preto}

Oliveira Viana (1981) alerta que o espírito republicano brasileiro era fortemente influenciado por três apelos: o liberalismo inglês, a democracia francesa e o federalismo americano. Contudo, segundo o autor, havia no país a absoluta ausência de uma classe social que pudesse ser suporte fático para tais ideais. Daí talvez se explique a importância dos militares nos estertores do séc. XIX no Brasil, já que militar não é classe. Marta Arretche não só chega à mesma conclusão que Viana, como também chega a outra, essa bem mais reveladora do país:

(...) o Brasil já era uma federação em 1834, quando não se declarava como tal, e não é uma federação até hoje, quando declara que é! Na base desse aparente paradoxo, um problema teórico-metodológico: a referência empírica para a construção do conceito de federação e das condições de emergência e evolução dos estados. (ARRETCHE, 2001, p 25).

Seja como for, na época, o sentido federativo prevaleceu e em uma sessão conturbada da Câmara, a proposta do voto de desconfiança contra o ministério Ouro Preto é aprovada com quase $80 \%$ de adesão. O imperador, então, dissolve a Assembleia em 17 de julho de 1889 e marca novas eleições para 31 de agosto daquele ano. Os eleitos assumiriam suas cadeiras no dia 20 de novembro, o que, como se sabe, não aconteceu, pois, cinco dias antes, a República já estava instalada. É curioso acompanhar o relato do próprio Visconde de Ouro Preto sobre os acontecimentos que são apresentados no já citado "Advento da ditadura militar no Brasil". Pelo que se depura da leitura, o Jornal País, em edição do dia 12 de novembro, acende o alerta final sobre a proximidade do golpe, ao afirmar que, em certa situação relatada (inteiramente irrelevante frente aos acontecimentos) o governo não teria como intervir "graças à infalível e próxima queda".

\footnotetext{
${ }^{7}$ As expressões foram retiradas do Manifesto Republicano disponível na Internet.
} 
Em reunião no mesmo dia 12 de novembro, o ministro da Guerra, o marechal e Visconde de Maracaju, beirando os seus 70 anos, mostrou-se tranquilo sobre qualquer questão que pudesse surgir, acrescentando ao chefe do gabinete que naquela mesma manhã havia falado com o ajudante-general, confirmando que tudo transcorria regularmente junto ao oficialato e à tropa. $\mathrm{O}$ citado ajudante-general era o mal. Floriano Peixoto.

É muito provável que, apesar de tudo, realmente imperasse no governo certa tranquilidade diante dos fatos que se avolumavam. Por exemplo, no dia 13 de novembro, Ouro Preto iria a Petrópolis despachar com D. Pedro, que provavelmente, mais despreocupado do que deveria, estava em seu palácio de verão. O próprio ministro não devia estar acometido de grandes aflições, pois não foi ao encontro com o monarca, porquanto alguém de sua família ficou adoentado e ele preferiu permanecer em sua residência no Rio de Janeiro.

Entretanto, no mesmo dia 13 o ministro da Justiça, Cândido de Oliveira, reencaminhou para Ouro Preto correspondência que havia recebido do marechal Floriano, onde se lia: "Há [sic] esta hora deve V. Ex.a ter conhecimento de que tramam algo por aí além: - não dê importância, tanto quanto seria preciso, confie na lealdade dos chefes, que já estão alerta. Agradeço ainda uma vez os favores que se tem dignado dispensar-me (...).” (Op. cit., 2017, p. 46)

Ouro Preto aciona novamente o Visconde de Maracaju apresentando a carta de Floriano Peixoto, e questionando o ministro militar sobre o "que se trama". O Ministro da Guerra alegou desconhecer o que a correspondência aventava e demonstrou-se seguro de que a tranquilidade e a lei não seriam abaladas. Então o Visconde de Ouro preto determinou que o ministro falasse com o ajudante-general Floriano Peixoto e o indagasse sobre as suspeitas que o induziram a se comunicar ao ministro da Justiça. Na mesma balada, indagou ao ministro sobre boatos quanto ao marechal Deodoro. "Nada me consta e suponho que não se envolverá em distúrbios, até porque está enfermo”, teria respondido Maracaju (Idem, p 47).

No fim da noite do dia 14, chegou ao presidente do gabinete a informação de que: "o primeiro regimento está em armas no respectivo quartel; comunicou ao ajudante-general que estava nessa atitude. Os chefes do Exército estão no quartel-general reunidos. Mandaram intimar o regimento para se desarmar"(Idem, p 50). Frente a tal informação, seguiu o Visconde para a secretaria de polícia, onde teve conversa com o marechal Floriano, o qual sugeriu que a Ouro Preto que acionasse a Marinha para apoiar as ações necessárias para 
contornar a sublevação que se iniciava. Mais que isso, o marechal se pôs a contatar os comandantes da armada. Tão solícito foi Floriano que Ouro Preto anotou em seu texto: "Fazia o sr. ajudante-general grande empenho, sobretudo, por não ter à sua disposição nenhuma força daquela arma.” (Idem, p 52). Floriano Peixoto ficou responsável pelo comando do que restava de apoio militar ao governo.

Entretanto, os membros do gabinete já percebiam que não haveria mais defesa. O visconde de Ouro Preto relata o que com espanto observou:

O fato é que se aproximavam forcas ameaçadoras e os batalhões que lhes deviam embargar o passo, formados no pátio interior do quartel-general, permaneciam com as armas em descanso. Nem se observava o movimento natural de quem se aparelha para combate, com a distribuição de cartuchame, a prontificação de ambulâncias, etc. Quem contemplasse aquela força suporia que ali se achava para uma simples parada, ou acompanhamento de procissão. (Idem Ibidem).

A situação parecia perdida e, quando o Visconde indagou aos oficiais da sua defesa porque deixaram que as tropas rebeladas tomassem posições estratégicas, e mais, se tal questão seria admissível no Paraguai, Ouro Preto teria ouvido de Floriano: "Lá tínhamos em frente inimigos e aqui somos todos brasileiros".

É claro que Floriano Peixoto estava inteirado de todos os planos traçados havia dias antes do golpe. Tanto é que Deodoro da Fonseca - que, vale destacar, era monarquista e amigo de D. Pero II -, na madrugada do dia 15 de novembro, alegando estar doente, indicou que chamassem Floriano para assumir o comando das unidades que deviam ocupar a cidade.

Quanto ao marechal Deodoro, pode-se ter certeza de que ele estava tão desconectado do movimento republicano que, ao depor, o ministério declarou "que se organizaria outro de acordo com as indicações que iria levar ao imperador" (BUARQUE DE HOLANDA, 1992, p. 360). E, para além disso, concluiu: "o imperador tem a minha dedicação, sou seu amigo, devo-lhe favores. Seus direitos serão respeitados e garantidos“ (Op. cit, 2017, p. 66).

\section{A guisa de conclusão: instala-se a República, não o federalismo}

Como se pode perceber, o golpe republicano foi muito mais um golpe de caserna, o que é possível explicar - e até faz certo sentido - diante da impossibilidade, à época, de alguma espécie de arranjo entre os políticos e, mesmo, a sociedade civil. Mas foi, até sob a ótica militar, um golpe curioso. Por exemplo, dos três marechais com papéis relevantes no evento, um, o Visconde de Maracaju, durante a crise estava mais interessado em desfrutar de 
sua residência no alto de Santa Teresa do que em intervir nas causas da rebeldia dos quartéis. Operou tardiamente e, quando o fez, o mínimo que se pode dizer é que agiu como de modo pueril.

O segundo, o marechal Deodoro, estranhamente comandou um golpe republicano, mas não queria a República, não estava preparado para ela e talvez sequer soubesse o que ela realmente significava. Pretendia, pessoalmente, apenas derrubar o gabinete Ouro Preto de quem não gostava. De toda maneira, permitiu que os eventos se precipitassem sem seu comando, o qual aparentemente nunca existiu.

Já o marechal Floriano esteve distante das conspirações republicanas - mas não dos interesses militares -, do marechal Deodoro da Fonseca e de outras lideranças do exército. Aguardou o desenrolar dos acontecimentos e somente decidiu com clareza seu lado na noite do dia 14 para 15 de novembro, quando, apoiado nas já citada frase "somos todos brasileiros", se recusou a cumprir a ordem do visconde de Ouro Preto para dispersar os rebeldes reunidos no Campo de Santana, no Rio de Janeiro.

Dirão alguns que no golpe não houve prevalência dos militares, que eles apenas foram o meio para atingir os objetivos dos partidos republicanos já presentes no Brasil. O marechal Floriano e os comandantes militares discordariam e diversos historiadores também. É preciso lembrar que pouco houve de harmonioso no governo provisório, que, a propósito, padecia de certo temor, quase uma síndrome, de movimentos conspiratórios, sendo que toda e qualquer reação contrária ou crítica ao governo - incluindo aquelas que se opunham as maléficas consequências da política do encilhamento promovida por Rui Barbosa - passaram a ser vistas como uma tentativa de restauração da monarquia. Foi assim que Deodoro afastou do governo grupos das próprias forças armadas não alinhados fielmente com o gabinete provisório, instituiu a censura à imprensa, fechou o Congresso (em novembro de 1891) e demonstrou sem pudor a face autoritária de seu governo.

Em seguida, Floriano Peixoto na presidência teve perfil mais caudilho ainda. Destituiu todos os eventuais aliados de Deodoro, inclusive governadores que o haviam apoiado. Debelou, com primores de violência, a Revolta da Armada e a chamada Revolta Federalista. Há, por exemplo, no caso da Revolta Federalista, vários registros de fuzilamentos (inclusive de estrangeiros), degola de prisioneiros etc. Além, é claro, do fato de que, quando retomou a cidade de Desterro, para deixar límpido A que veio, rebatizou-a como Florianópolis, a cidade 
de Floriano. ${ }^{8}$

A par das preocupações, quase paranoicas, quanto a eventuais movimentos restauradores, a verdade é que, após o golpe republicano, a resistência monárquica inexistiu. Provavelmente apenas a segunda Revolta da Armada teve- sob o comando do almirante Saldanha da Gama - alguma inspiração monarquista. Entretanto, ela só ocorre em 1893, com a República já consolidada.

Cabe uma breve observação, pois a assertiva de que a República rapidamente se consolidou não pode ser confundida com a consolidação do governo republicano, o que não ocorreu. Por seu turno, a consolidação da República decorreu das circunstâncias que a propiciaram em um particular momento histórico do Brasil. Há, por exemplo, diversos relatos de que as insígnias imperiais foram quase que imediatamente abandonadas e que o já citado espírito federalista se estabeleceu quase que instantaneamente na população. Afinal, em tempos republicanos, ajamos como republicanos.

Ocorre que, como já salientado, nossa visão de federalismo era fortemente influenciada pelo sistema adotado nos Estados Unidos da América, mas nossa realidade era diferente daquele país, onde colônias inglesas, de certa maneira independentes umas das outras, conseguiram garantir a autonomia e a maior parte das competências nos Estados quando adotaram a União. No Brasil, ao contrário, tentamos sair de um Estado centralizado do período imperial para uma ordem federativa com divisão de poderes e competências entre antigas províncias que não possuíam histórico de autonomia ou experiências e instituições que pudessem garantir o federalismo.

Ademais, José Murilo de Carvalho (1987) alerta que nem mesmo entre os republicanos havia consenso sobre o tipo de República que pretendiam estabelecer. Para se ter uma ideia de dificuldade entre os políticos, o historiador atribui a Campos Sales a alocução de que a falta de coesão do Partido Republicano na corte era o principal obstáculo ao desenvolvimento da ideia republicana.

Em sentido oposto, as 13 ex-colônias britânicas já em 1777 (em meio à guerra civil americana) celebraram um tratado entre si, criando o que foi chamado de The Articles of Confederation and Perpetual Union. O art. 10 do tratado define: "Art. X. The power not

\footnotetext{
${ }^{8}$ Formalmente foi Hercílio Luz - presidente de Santa Catarina - que sancionou a mudança do nome da cidade, em um movimento dos republicanos catarinenses de apoio e exaltação ao Marechal de Ferro.
} 
delegated to the United States by the Constitution, nor prohibited by it to the states, are reserved to the states respectively or to the people"

Ou seja, pelo tratado, qualquer coisa que não for definida como função da União é delegada aos estados ou ao povo. Aqui cabe destaque que o sentido da palavra povo talvez seja a principal diferença entre as duas repúblicas e seus respectivos conceitos de federação. Notem que nossa Constituição de 1891 traz em seu primeiro artigo a declaração de que: "Art $1^{\circ}$ - A Nação brasileira adota como forma de Governo, sob o regime representativo, a República Federativa, proclamada a 15 de novembro de 1889, e constitui-se, por união perpétua e indissolúvel das suas antigas Províncias, em Estados Unidos do Brasil."

Portanto, estabelece uma federação pela união de estados. O curioso, porém, é que nossa primeira Constituição só utiliza a palavra povo em duas ocasiões. A primeira delas no art. 28, tratando de deputados (representantes do povo) e depois apenas no art. 81, que trata de revisão de matéria de crime. Com o poder do povo deixado de lado, parece que o objetivo da Carta de 1891 é, então, o de adaptar discursivamente os princípios federalistas, de maneira que, com tal narrativa, conseguisse preservar os interesses e regalias das mesmas elites agrárias e burocráticas que controlaram o Império.

Assim, o golpe instigado e justificado pelos princípios do ideário federativo cria os Estados Unidos do Brasil, mas não constitui uma verdadeira federação no sentido de clareza quanto às competências e à autonomia dos Estados membros. É bem mais um golpe militar orquestrado pelo receio de um ministério apontado como hostil aos militares. Apesar de tudo, não deixa de ser curioso que, em 1894, o golpista Floriano Peixoto transmita tranquilamente o cargo a Prudente de Moraes, este sim um histórico republicano e primeiro presidente civil do novo regime.

\section{Referências}

ABREU M. P; LAGO, L. A economia brasileira no Império, 1822-1889. Textos para Discussão, PUC-RJ, n. 584. 2001.

AMORIM, R. $O$ futuro $d a$ economia brasileira. Disponível em: <https://www.youtube.com/watch?v=K4_wMcaoutI>. Acesso em: 17 jan. 2020.

ARRETCHE, M. Federalismo e democracia no Brasil: a visão da ciência política norteamericana. São Paulo em Perspectiva, v. 15. n 4. Ouc /Dec. 2001. Disponível em < http://www.scielo.br/pdf/spp/v15n4/10369.pdf?origin=publication_detail> Acesso em 28 jan. 2020. 
BONAVIDES, P. Política e Constituição: os caminhos da democracia. Rio de Janeiro: Forense, 1985

BRASIL. IPEA. História - Império de crises. Disponível em: $<$ http://www.ipea.gov.br/desafios/index.php?option=com_content $\&$ view=article\&id=2572:c atid=28\&Itemid=23> . Acesso em: 17 mai. 2019.

BUARQUE DE HOLANDA, S. História geral da civilização brasileira: Do Império à República. Tomo II. Rio de Janeiro: Bertrand Brasil. 1992. v. 7.

CARONE, E. A evolução industrial de São Paulo (1889-1930). São Paulo: Editora SENAC, 2001.

Cartas de D. Pedro II à Princesa Imperial. Disponível em: <https://idisabel.files.wordpress.com/2011/06/cartas-de-pedro-ii-a-princesa-imperial.pdf >. Aceso em 16 fev. 2020.

CARVAlHO, J. M. Os bestializados, o Rio de Janeiro e a República que não foi. São Paulo: Companhia das Letras, 1987.

FERNANDES, F. A revolução burguesa no Brasil: ensaio de interpretação sociológica. Rio de Janeiro: Zahar Editores, 1975.

A integração do negro na sociedade de classes. São Paulo: Dominus Editora e Editora da USP, 1965. v. 1.

FREYRE, G. Sobrados e mucambos. Rio de Janeiro: Record, 1990.

FURTADO, C. Formação econômica do Brasil. Rio de Janeiro: Fundo de Cultura, 2003.

GAMBI, T. O debate político e o pensamento econômico no Império brasileiro: centralização de poder e monopólio de emissão no segundo Banco do Brasil (1852-1853). Almanack, n.09, abril de 2015. Disponível em: <http://www.scielo.br/pdf/alm/n9/22364633-alm-9-00176.pdf> Acesso em 12 jan. 2020.

Manifesto do Partido Republicano. Disponível em: $<$ https://edisciplinas.usp.br/pluginfile.php/4360902/mod_resource/content/2/manifesto\%20r epublicano\%201870.pdf>. Acesso em: 17 fev. 2020.

MELLO. E. C. Um imenso Portugal - História e historiografia. Rio de Janeiro: Editora 34, 2002.

MOGGRIDGE, D. E. Problems in the History of the international economy since 1870: The gold standard. Textos para Discussão, PUC-RJ, n. 160, abr. 1987.

NOVAIS, F. Caio Prado Jr. na historiografia brasileira. In: NOVAIS, F. Portugal e Brasil na crise do antigo sistema colonial (1777- 1808). São Paulo: Hucitec, 1979.

O Brasil nos quadros do antigo sistema colonial. In: MOTA, C (Org). Brasil em perspectiva. São Paulo: Difusão Editorial. 1977. 
OURO PRETO. Advento da ditadura militar no Brasil. Edições do Senado Federal. Vol. 243. Brasília: Conselho Editorial - CEDIT, 2017. v. 243.

PROUDHON, P. J. O princípio federativo. São Paulo: Imaginário, 2001.

RODRIGUES, J.A (Org.). Vilfredo Pareto: Sociologia. São Paulo: Ática, 1984.

SCHWARCZ, L. M. As barbas do Imperador: D. Pedro II, um monarca nos trópicos. São Paulo: Companhia das Letras, 1998.

SODRÉ, N. W. Síntese de história da educação brasileira. Rio de Janeiro: Bertrand Brasil, 1994.

VIANA, O. O idealismo na Constituição. In: CARDOSO, V. (Org,). À margem da historia da República. Brasília: Editora Unb, 1981

O idealismo na evolução política do Império e da República. São Paulo: Biblioteca O Estado de São Paulo, 1922. 